\title{
Non-Profit Islamic Institutions and Quality Management Systems in Malaysia
}

\author{
Mohd Sadiq Mohd Mokhtar ${ }^{1} \&$ Fadzila Azni Ahmad $^{1}$ \\ ${ }^{1}$ Centre for Islamic Development Management Studies (ISDEV), Universiti Sains Malaysia, Malaysia \\ Correspondence: Fadzila Azni Ahmad, Centre for Islamic Development Management Studies (ISDEV), Universiti \\ Sains Malaysia, 11800 USM, Penang, Malaysia.
}

Received: September 29, 2020

Accepted: December 10, 2020

Online Published: December 11, 2020

doi:10.5430/ijhe.v10n3p16

URL: https://doi.org/10.5430/ijhe.v10n3p16

\begin{abstract}
This paper presents a narrative review of arguments made by researchers regarding the applicability of western and Japanese quality management systems by non-profit Islamic institutions. This review approach was employed after undertaking a literature search for selected articles based on the inclusion and exclusion criteria. The focus of narrative reviews in this study is to identify common themes across researches regarding non-profit Islamic institutions and quality management systems in Malaysia that can then be used to identify commonalities and critical differences among included documents. Following electronic searches of Scopus and Google Scholar sites, nine studies on quality management systems related to non-profit Islamic institutions were identified and subjected to a detailed narrative literature review. Findings reveal that the quality management systems discussed by researchers vary and there are researchers who rejected the idea of implementing western and Japanese quality management systems and instead implemented the Islamic Quality Management system, which was developed in Malaysia. This study intends to contribute to the quality of management and non-profit institution management literature with the proposition of adopting quality management systems by the management of non-profit Islamic institutions.
\end{abstract}

Keywords: quality management system, non-profit Islamic institutions, Malaysia, narrative review

\section{Introduction}

Malaysia is an Islamic country in which the majority of the population are Muslims. Islam is also the religion of the Federation as mentioned in the Malaysian constitution (Wan Ali et al., n.d.). Therefore, the Islamic development institution has become an important institution for Muslims in Malaysia. Islamic institutions are defined as institutions that endeavour to fulfil the objectives of Islamic-based development in every aspect of activities implemented although it is yet to be fully implemented (Ahmad, 2016b; Nugroho et al., 2017). Therefore, the existence of Islamic institutions is important in Malaysia in order to fulfil the Islamic objective of development held by the individual, society or the nation as a whole. Generally, these Islamic institutions can be categorised based their core activities. Ahmad (2016a) argued that Islamic institutions in Malaysia are categorised into several categories, such as Religious Obligation Institutions (i.e. National Mosque Kuala Lumpur and Putra Mosque in Putarajaya), Education Institutions (i.e. Institute of Islamic Understanding Malaysia or IKIM, International Islamic University Malaysia or IIUM), Banking Institutions (i.e. Bank Islam Malaysia Berhad - BIMB, Bank Muamalat Malaysia Berhad - BMMB), Financial Institutions (i.e. Lembaga Tabung Haji - TH, Syarikat Takaful Malaysia Berhad STMB), Socio-Economic Institutions (i.e. Zakat Pulau Pinang; The Federal Territory Tithe Collection Method), Administrative Institutions (i.e. Department of Islamic Development Malaysia - JAKIM, Wakaf, Zakat and Hajj Department - JAWHAR), and Legislative Institutions (i.e. The Syariah Judiciary Department).

However, this study only focused on non-profit Islamic institutions rather than a particular organisation. There are numerous definitions of an institution and it is an entity that is well known in social science studies for many years. North (1990) mentioned an analogy that regards institutions as "rules of the game" and organizations as "the players" when explaining the distinction between both variables. However, Hodgson (2006) disagreed with this terminology because he felt there are no clear distinctions between organizations and institutions and an organization is a special kind of institution. This current study does not focus on the distinction between both these terminologies and the two terminologies are similar in nature, as mentioned by Hodgson (2006). This study regards non-profit Islamic institutions as an Islamic institution that pursues Islamic-based non-profit activities and mission-oriented goals 
through the collective actions of citizens. Hence, based on the terms chosen by this study, institutions that generate profits have been omitted, such as banking and financial institutions.

Islamic banking and financial institutions in Malaysia have become global leaders in this field (Abdullah,2019). As mentioned by the Malaysian Deputy Minister of Finance, Amiruddin Hamzah, Malaysia continues to be the main driver of the Sukuk market and represents $49.7 \%$ of the total global outstanding Sukuk. Malaysia represents the largest Islamic fund market with 35.8\% of total industry assets under management and Malaysia ranks first (28.3\%) with 430 funds out of the total global number of funds (INCIEF, 2019). This shows that Malaysian Islamic financial and banking institutions have been exceptional and become a role model for other Islamic nations around the globe. However, the significance of Islamic financial institutions is not on par with the performance of non-profit Islamic development institutions in Malaysia. The efficiency and performance of non-profit Islamic institutions must be improved, especially at the management level (H. A. B. Mohamed et al., 2016; Mohd Noor et al., 2012).

Therefore, the management system is a vital element for improving and preserving quality. Among the most discussed type of management in Malaysia is the quality management system. Since the time of the $4^{\text {th }}$ Prime Minister of Malaysia, Tun Mahathir Mohamad, Malaysia had introduced a policy called the "Look East Policy" (LEP) in 1982. Kawabe (1991) mentioned that LEP seemed to popularize Japanese style management, which led to the first batch of government and private sector employees going to Japan to study Japanese management skills. This initiative had benefitted not only these two sectors but the education sector as well, which saw many students from Malaysia going to Japan to study and adopt Japanese values and work ethics (Lazim, 2011). However, Loh, Wei, \& Suzuki (2015) and Sundaram (2014) argued that the sector that benefitted the most from LEP was industrialization, more specifically heavy industrialization, which has increased in productivity and efficiency. These benefits have helped the Malaysia economy flourish throughout these years. Due to the benefits attain from LEP, after winning the election in May 2018, the same individual who become the $7^{\text {th }}$ Prime Minister of Malaysia, Tun Mahathir Mohamad, had visited Japan in June 2018 and announced the continuation of LEP.

However, Malaysia regards this re-implementation of LEP as Look East Policy 2.0 (MITI, 2019). In a speech by Tun Dr Mahathir Mohamad on March 2019, he argued that the Malaysian government will re-implement LEP to emulate noble values and beliefs held by the Japanese in their quest for success (Prime Minister's Office, 2019). This shows that the Malaysian government is still committed to learning management skills and systems from the Japanese. Even though LEP benefits the manufacturing industry, the Malaysian government is committed to propagating the Japanese management system concept to all sectors in Malaysia, including the public sector. This is indicative when TQM was introduced in Malaysia when the then Prime Minister of Malaysia established a movement called Gerakan Budaya Kerja Cemerlang (Excellent Work Culture Movement) in 1989, whose objective was to improve the quality of life by improving the quality of the working culture (Mahathir Mohamad, 1992). Since then, numerous organizations and institutions have implemented TQM, and this includes Islamic institutions.

In a similar vein, Malaysia has initiated another quality management system known as the Islamic Quality Management System. As an Islamic country, Malaysia has taken a step further and become the pioneer in Islamic Quality Management Standards by introducing MS1900 known as Islamic Quality Management Standards (Othman, 2016). The MS 1900 QMS was created to fill the existing gap in the ISO 9000 standard, which concentrates on product or external output aspects alone, and not on the internal or spiritual aspects. Thus, MS 1900 was formulated in 2005 by a special committee known as the Malaysian Industry Standards Committee on Halal Standards (H. A. B. Mohamed et al., 2016). Hence, this shows that Malaysia is serious in the development and management of the nation's Islamic institutions.

The significant move by Malaysia to develop Islamic institutions has caught the attention of researchers studying quality management systems that have or should be implemented by Islamic institutions. In addition, the development of various quality management systems, including those based Islamic perspectives such as MS1900, have been a topic of interest, especially regarding the applicability of those management systems by non-profit Islamic institutions. Therefore, this study intended to examine previous literature on quality management systems adopted by non-profit Islamic institutions. In order to achieve the objectives of this study, it has to answer two questions, namely (1) What are the types of quality management concepts and types of non-profit institutions discussed in the selected articles, and (2) What are the researchers' perspectives on the applicability of the quality management systems discussed by non-profit Islamic institutions?

\section{Aims and Contributions of This Study}

This study focuses on quality management systems in Malaysian non-profit Islamic institutions. A status picture of various types of quality management systems applied and researchers' comments about the application of quality 
management systems are presented. In this study, the application of quality management systems by non-profit Islamic institutions is a key concept that plays a vital role in the institution's success. The aim of this review is to identify various ideas across studies regarding non-profit Islamic institutions and quality management systems in Malaysia in order to identify the commonalities and differences. The current study is an exploratory narrative review that aims to provide an understanding of quality management systems in Malaysian non-profit Islamic institutions. The main contribution of this study is a scientific evidence on the application of various quality management systems rooted in either western, eastern or Islamic paradigms by the management of non-profit Islamic institutions.

\section{Methodology}

As mentioned earlier, the narrative review method used in this study explains the research questions related to Quality Management Systems and Islamic non-profit institutions. Alongside the systematic review, the narrative review falls under the qualitative meta-analysis category. The narrative review concept includes the clarification of research issues in the interpretation of a document's main content that focuses on texts and language (Ferrari, 2015). Narrative reviews usually revolve around the qualitative aspects. Pursuant to Ferrari (2015), the manipulation of statistical data involving the synthesis of evidence relevant to a wide range of questions, including the primary use of words and text to summarise and explain the results of multiple studies, involves narrative reviews. This view is consistent with Siddaway, Wood, and Hedges (2019), who argued that a narrative review is a useful means to develop or evaluate a new theory by linking numerous studies on different subjects for reinterpretation or interconnection. This fact could be linked to this study because its aim is to link all research done in Malaysia on quality management systems and non-profit Islamic institutions.

In deciding the appropriate articles, two search techniques were used, namely internet-based and manual searches. First, as the principal search engine, two internet-based databases (Scopus and Google Scholars) were used. The search terms were based on partnership between Quality Management, Quality Control and Islamic non-profit institutions papers, which are published in top-referred journals. In order to retrieve the abstracts and where necessary, the full-text posts, databases were again used. This study used narrative reviews by including studies written in English and Malay Languages, studies that are published in full and the literature review part is critical, while dissertation articles, editorials, letters, conference proceedings, chapters of books and books are excluded. In the narrative review process, inclusion and exclusion requirements are emphasised to obtain precise and diligent papers and research records. The inclusion steps include the title and abstract of the keyword search term "quality". This opens up a broader spectrum of quality viewpoints. This action was taken before the exclusion measures were further taken into account (Ferrari, 2015; Siddaway et al., 2019).

After the related inclusion and exclusion criteria were drawn up to eliminate data collection biases, the selection criteria must be set out accordingly when discussing the pre-determined objectives. Requirements for exclusion apply to the rejected selection steps set out in the search process to address the study's research objectives. Inclusion is usually based on the reading of abstracts, while exclusion is based on the restriction of details found in complete papers. The exclusion criteria must be based on the reading of abstracts and also full texts, if necessary. The complete version of a majority of texts used were downloaded from university libraries. The subscription of journals by the university allows complete texts to be easily accessed. In the case where full texts were not available from the university library, the manual approach was used through other search engines or by manually requesting the full text directly from the authors of the papers.

The selection criteria for articles in narrative reviews are illustrated in Figure 1. The inclusion and exclusion criteria establish the direction for aligning the research objectives of this paper. 


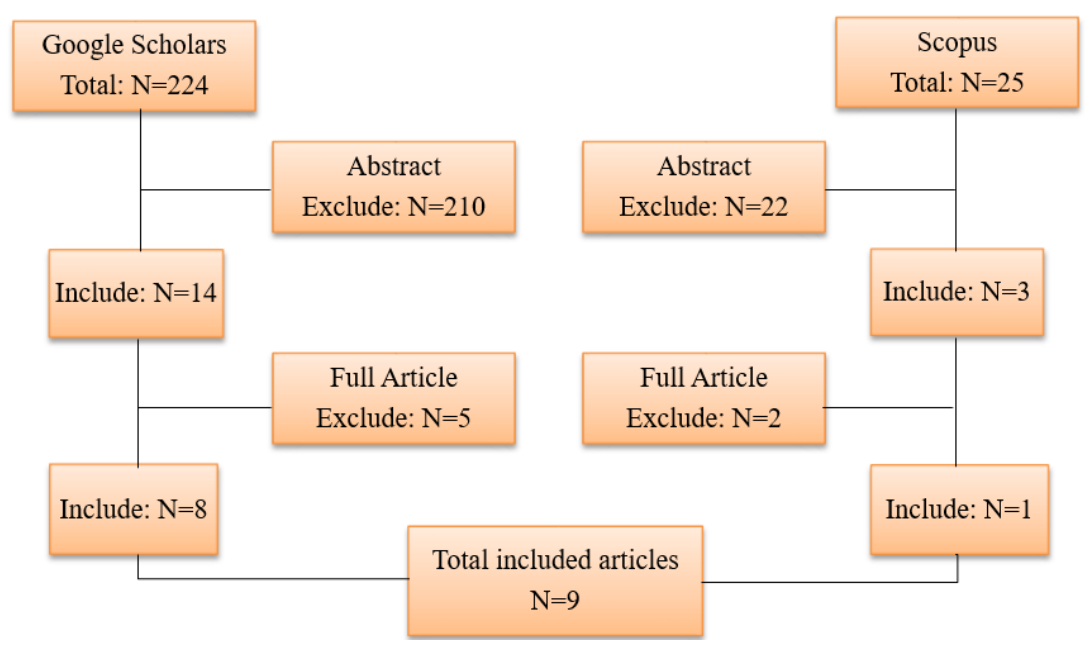

Figure 1. The Process of Searching and Its Findings

\section{Results and Discussions}

The total amount of articles reviewed were 249, comprising 224 obtained from Google Scholars and 25 from Scopus. However, after reviewing these articles based on the inclusion and exclusion criteria, only 9 articles were selected for narrative review since it met the stipulated criteria. The selected articles were authored by Hasan Al-Banna, Ab. Mumin, and Siti Arni (2013), Jaafar, Habidin, Hussin, Zakaria and Hamid (2013), Ahmad (2015), Ali, Basir and Ahmadun (2015), Sanusi, Tajuddin, Takril and Affandi (2015), Mohamed, Ab. Ghani \& Basir (2016), Hasliza, Siti Arni and Musaiyadah (2016), Basir, Azmi, Ismail, Ibrahim and Mohamed (2017) and Rashid, Wahid and Ahmad (2018).

Based on the 9 articles, it was found that 4 categories of non-profit Islamic institutions had been the focus of these studies. Figure 2 below shows the categories of non-profit Islamic institutions that were the focus of the 9 articles.

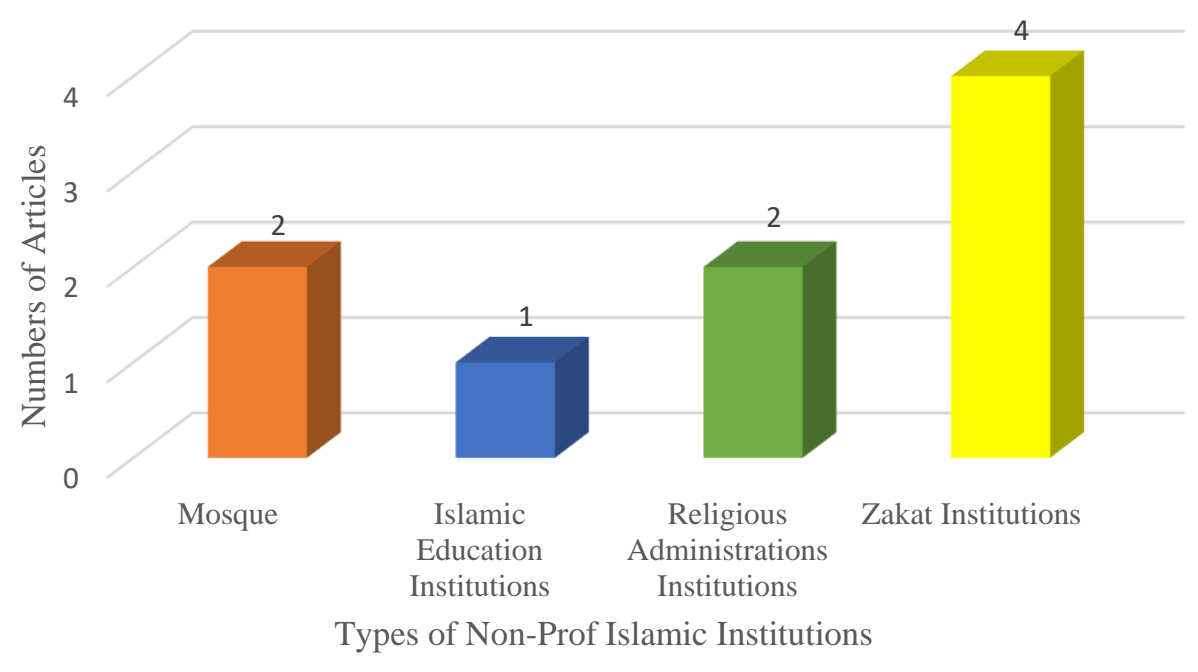

Figure 2. The number of articles and the types of non-profit Islamic institutions

\section{Source: Data Processed}

According to Figure 2 above, the types of non-profit Islamic institutions most discussed by previous studies were the Zakat institution, followed by the religious administrative department, mosques and finally, Islamic education institutions. Figure 2 provides details about the number of articles based on the type of non-profit Islamic institutions. 
Next, Figure 3 indicates that all the non-profit Islamic institutions in these 9 studies had applied either the conventional quality management system, which is a quality management system that originated outside the Islamic paradigm or the Islamic quality management system. Figure 3 specifically shows that Malaysia Quality Management from an Islamic Perspective (MS1900) had dominated discussions among researchers and it has been implemented by three different Islamic institutions, mainly Zakat institutions, religious administration institutions and also Islamic education institutions. Other types of management models are the 7S McKinsey Model, Total Quality Management Fast Track Model (TQM), Kaizen, 5S and Quality Management, specifically relevant to the provision of services. This shows that Malaysian non-profit Islamic institutions not only implement Quality Management from an Islamic perspective (MS1900) but also quality management models from the west and Japan, such as TQM - the Fast-Track model, 5S and Kaizen. However, the studies' perspective on the applicability on these management systems by non-profit Islamic institutions differs.

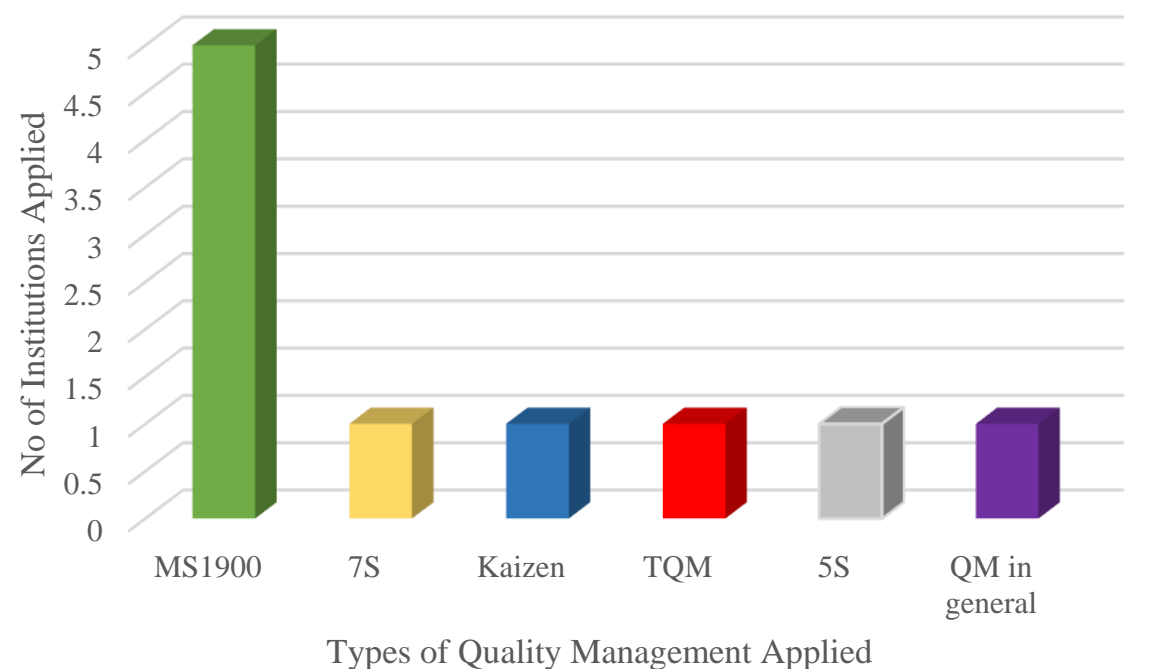

Figure 3. The number of non-profit Islamic institutions and the quality management system adopted

\section{Source: Data Processed}

In most of these studies, discussions have tried to relate the application of quality management systems with Islamic values. Hasan Al-Banna, Ab. Mumin, and Siti Arni (2013), who studied Zakat institutions that applied MS1900, argued that the Tawhid concept is the core element in the implementation of MS1900, which refers to the full submission to Allah SWT in order to achieve the blessings of Allah SWT. Institutional activities not only focus on the technical aspects of MS1900 but also the spirituality and humanistic aspects, such as Islamic ethics in occupation and religious activities, such as daily recitals of the Quran to improve one's spirituality.

Meanwhile, Jaafar, Habidin, Hussin, Zakaria and Hamid (2013) suggested that Kaizen is a form of Strategic Management that boosts the quality of mosque management. The study stated that strategic management can be a tool for understanding any changes and strains that affect a mosque. Therefore, it reveals problems or predicts future problems that the mosques might encounter. Strategic management helps the mosque to achieve success. The continuous improvement in mosque management will attract more Muslims to come to the mosque and enliven the atmosphere in mosques. Ahmad (2015) also studied mosques as the focus of quality management practices of Islamic institutions. However, Ahmad (2015) disagreed with the implementation of the 7S Management Model by mosques after evaluating the concept based on Islamic worldview, epistemology and ontological aspects. The management system implemented by Islamic institutions, particularly mosques, must be based on these aspects that are rooted in Islamic philosophy. Furthermore, all aspects of Islamic institutions, including the management system, must be based on Tawheed (Unity of God) towards Allah SWT, the Creator.

Despite being formulated from the conventional management paradigm, Ali, Basir and Ahmadun (2015) argued that some Islamic Quality Concept aspects suggested by MS 1900:2005 do not solely look into the benefits in the materialistic world. The appreciation of Islamic values improves the quality of work, which in turn helps to attain eternal success (al-Falah) in this world and in the afterlife. According to Ali, Basir and Ahmadun (2015), the main 
principle to uphold in any task, no matter how small it is, can become a form of worship as long as it follows Sharia guidelines, even when applying MS1900: 2005.

As for Sanusi, Tajuddin, Takril and Affandi (2015), their study tried to prove that the implementation of TQM by Zakat institutions has a positive relationship with quality performance in terms of business performance and best practices even though Zakat institutions are non-profit Islamic development institutions. The most significant positive aspect is the enhancement of customer confidence. The institution that implements the conventional quality management system, such as TQM and 5S, can become a role model for other Islamic institutions.

However, Mohamed, Ab. Ghani \& Basir (2016) identified a gap in the application of the conventional quality management system. The study found that quality management from an Islamic perspective in the form of MS1900, could fill the gap. The gap can be filled not only by focusing on materialistic aims but also the aim to achieve success in worldly affairs and matters in the afterlife. Hasliza, Siti Arni and Musaiyadah (2016), who studied the application of MS1900 at JAWHAR, argued that the implementation of MS1900 in JAWHAR is consistent with the aims of JAWHAR, which is to become a world-class government department. Among the benefits outlined by these researchers are fulfilling the client's charter, which increases customer satisfaction and fulfils customer needs. Besides that, JAWHAR was found to be an outstanding religious department because it implemented MS 1900 and this helped build a better public image. JAWHAR also improves job management as it has become systematic, up-to-date, complete, organized and functions in an orderly manner due to the application of MS1900 standards.

Basir, Azmi, Ismail, Ibrahim and Mohamed (2017) observed that the implementation of MS1900 in the Malacca Zakat Centre has driven the institution to comply with Halal and Haram principles, operate based on Islamic values and make decisions in accordance with the objectives of Sharia. Besides that, religious and spiritual practices are also emphasized by the Malacca Zakat Centre, namely, religious briefings and Qur'an recitals. Thus, Basir, Azmi, Ismail, Ibrahim and Mohamed (2017) concluded that the implementation of MS1900 by the Malacca Zakat Centre does not only focus on technical aspects, like documentation and audits, but also emphasizes religious aspects, such as an interest-free financial system, zero corruption status and safeguarding the interests of staffs. In other words, the study found that the implementation of MS1900 by MZC is delivered holistically as required by Islam.

Rashid, Wahid and Ahmad (2018) suggested that the quality management system implemented by non-profit Islamic institutions, such as Zakat Institutions, must be based on moral values (akhlak) and worship (ibadah). The existing quality management system was found to lack the support for zakat institutions to achieve the blessings of Allah SWT (mardhatillah). However, Rashid, Wahid and Ahmad (2018) agreed that the technology must be adopted by zakat institutions in order to improve the quality of their management system.

Jaafar et al. (2013) and Sanusi et al. (2015) suggested that non-profit Islamic institutions, such as mosques and zakat institutions, should implement Japanese management systems, for example, Kaizen and 5S. Both researchers argue that the implementation is beneficial to non-profit Islamic institutions in the form of improving the confidence of stakeholders, improving the institution's image and attracting more people to the institution (Jaafar et al., 2013; Sanusi et al., 2015). However, Sanusi et al. (2015) argues that zakat institutions that implement TQM (the fast track model), in this case the Malacca Zakat Centre, have demonstrated a positive relationship with the institution's quality performance in terms of business performance and best practices although zakat institutions are actually religious-based non-profit institutions. Even though the implementation of western and Japanese management shows a positive result, some researchers like Ahmad (2015) disagree with the implementation.

According to Ahmad (2015) and also researchers like Nugroho et al. (2020), the implementation of any management system by Islamic institutions must be based on Islamic philosophy. The three aspects of Islamic philosophy, which are basic Islamic worldview (tasawur), epistemology and ontology, must be the fundamentals in the development of a management system (Ahmad, 2015). From the tasawur aspect, many conventional management systems from the West and Japan focus only on profit maximization. In this circumstance, the management system, which mainly focuses on customer satisfaction, is unsuitable (Ahmad, 2015). This is evident in studies by Jaafar et al. (2013) and Sanusi et al. (2015), which shows that the biggest benefit of implementing conventional management systems is customer satisfaction. However, this aim and premise contradicts the three main principles of Islamic tasawur, which is Allah SWT as the Creator and both humankind and nature as creatures of the Creator (Salleh, 2003). Therefore, this contradiction questions the applicability of conventional quality management systems.

From epistemology and ontology perspectives, the quality management system relies on common knowledge (ilmu daruri), which is solely based on arguments by the human mind and concepts behind these quality management models are dissimilar to Islamic concepts. Thus, this makes conventional quality management systems unsuitable for implementation by Islamic institutions, especially non-profit Islamic institutions (Ahmad, 2015). Rashid, Wahid and 
Ahmad (2018) also argued that quality management systems adopted by Islamic Institutions, such as Zakat Institutions, must be based on akhlak and ibadah so that it is consistent with the focus of non-profit Islamic institutions that aim to achieve mardhatillah. This argument is consistent with studies by Ahmad (2015) and Salleh (2003), who stated that the ultimate objective of any management model adopted by Islamic institutions, such as mosques, must be to secure the blessings of Allah SWT (mardhatillah).

According to Mohamed et al. (2016), Malaysia had initiated MS1900 to fill the gap made by the unwillingness to adopt conventional quality management systems. The gap filled by MS 1900 not only focuses on materialistic aims but also the aim to achieve success in worldly affairs (dunya) as well as in the afterlife (akhirah) (Basir et al., 2017; Mohamed et al., 2016; Nugroho et al., 2019). This is strongly indicative in non-profit Islamic institutions that have implemented MS1900, in which religious practices are regularly practiced (recital of the Quran), not only by focusing on documentation but also emphasising on religious aspects (Ali et al., 2015, 2016; Basir, et al., 2017; Mohamed et al., 2016). However the ultimate benefit of implementing of MS1900 as highlighted by most researchers is similar to the implementation of conventional quality management systems, which is improving customer confidence as well as work and service quality (Ali et al., 2015, 2016; Basir et al., 2017; Mohamed et al., 2016). Therefore, most studies are of the view that MS1900 is the most suitable quality management system for non-profit Islamic development institution.

\section{Conclusion}

This review found that studies on quality management systems and non-profit Islamic development institutions can be categorised into two groups, namely studies that propose a quality management model from the west or east or the Malaysia Sharia Compliant MS1900 to be implemented in institutions. Conversely, the zakat institution has become the most discussed non-profit institution by previous researchers. Another point is that this review also found that the MS1900 model has filled the gap which was found in the conventional management system. As for future research, this study found the urgency to analyse MS1900 according to at least three aspects of Islamic philosophy, namely worldview, epistemology and ontology. More non-profit Islamic institutions should be reviewed and analysed, such as tahfeez schools and Islamic administrative institutions, for example, Waqf management centres. Above all, the review of quality management systems adopted by non-profit Islamic institutions should be further discussed to ensure these institutions implement a holistic quality management model that is based on Islamic philosophy and does not neglect materialistic improvements in the management of non-profit Islamic institutions.

\section{Acknowledgements}

*The authors would like to acknowledge the financial support provided by the Bridging (Khas) Grant (304/CISDEV/ 6316257) from Universiti Sains Malaysia, Malaysia.

\section{References}

Abdullah, A. (2019, February). Malaysia a global leader in Islamic Banking. New Straits Times Press (M) Bhd.

Ahmad, F. A. (2015). The Applicability of The Conventional Management Model In Mosque Manegement: An Evaluation. International Research Journal of Human Resources and Social Sciences, 2(11), 1-16.

Ahmad, F. A. (2016a). Konsep Pengurusan Institusi Pembangunan Berteraskan Islam (2nd Ed.). Dewan Bahasa dan Pustaka.

Ahmad, F. A. (2016b). Strategic Human Management Practices in Islamic Development Institutions in Malaysia: an Islamic Worldview Analysis. Proceedings of INTCESS2016 3rd International Conference on Education and Social Sciences, 10, 10-18. http://www.ocerint.org/intcess16_epublication/papers/11.pdf

Ali, H. M., Basir, S. A., \& Ahmadun, M. (2015). The issues of implementing Islamic Quality Management System MS1900: 2005 Certification at the Department of Awqaf, Zakat and Hajj (JAWHAR). Online Journal of Research in Islamic Studies, 2(1), 14-28.

Ali, H. M., Basir, S. A., \& Ahmadun, M. (2016). Implementation of the islamic quality management system MS1900 and its benefits: A case study at the department of Hajj, Waqf and Zakah, Malaysia. Global Journal Al-Thaqafah, 6(2), 85-98. https://doi.org/10.7187/GJAT11620160602

Basir, S. A., Abdul Ghani Azmi, I., Syed Ismail, S. H., Ibrahim, P., \& Mohamed, H. A. (2017). Malaysian Islamic quality management system MS1900: An implementation steps at Malacca Zakat Center. Humanomics, 33(2), 239-254. https://doi.org/10.1108/H-10-2016-0078

Basir, S. A., Azmi, I. A. G., Ismail, S. H. S., Ibrahim, P., \& Mohamed, H. A. (2017). Malaysian Islamic quality 
management system MS1900: An implementation steps at Malacca Zakat Center. Humanomics, 33(2), 239-254. https://doi.org/10.1108/H-10-2016-0078

Ferrari, R. (2015). Writing narrative style literature reviews. The European Medical Writers Association, 24(4), 230-236. https://doi.org/10.1179/2047480615Z.000000000329

Hodgson, G. M. (2006). What Are Institutions. Journal of Economic Issues, 40(2), 493-500. https://doi.org/10.1080/00213624.2006.11506928

INCIEF. (2019). Speech By Yb. Dato' Ir. Haji Amiruddin Hamzah Deputy Finance Minister, Malaysia Islamic Finance Innofest 2019. INCIEF.

Irvin, R. (2017). Nonprofit organization. In Encyclopaedia Britannica. Encyclopædia Britannica, inc.

Jaafar, A., Habidin, N. F., Hussin, M. Y. M., Zakaria, Z., \& Hamid, A. A. (2013). Relationship Between Strategic Management $(\mathrm{Sm})$ and Kaizen Management System (Kms) in Mosque Management. BEST: International Journal of Management, Information Technology and Engineering (BEST: IJMITE), 1(3), 15-20.

Kawabe, N. (1991). Problems of and Perspectives on Japanese Investment in Malaysia. In S. Yamahita (Ed.), Transfer of Japanese Management to the ASEAN Countries (pp. 239-266). University of Tokyo Press.

Lazim, A. S. (2011). Dua Dekad Dasar Pandang ke Timur: Satu penilaian aspek pendidikan (1982-2002). Penerbit Universiti Pendidikan Sultan Idris.

Loh, J., Wei, S., \& Suzuki, A. (2015). Three Decades of Malaysia-Japan Relations (1981-2011): Crossed Interests and Missed Opportunities, 4(1), 73-100.

Mahathir Mohamad, T. (1992). Ucapan Y.A.B. Perdana Menteri Dr. Mahathir Bin Mohamad di Pelancaran Gerakan Budaya Kerja Cemerlang.

MITI. (2019). MITI Media release 2nd_Bilateral Coordinating Committee between Japan and Malaysia.

Mohamed, H. A. B., Ab. Mumin, A. G., \& Basir, S. A. (2013). Sistem pengurusan Islam yang berkualiti mampu menjamin kepuasan pekerja: Suatu realiti dan cabaran masa hadapan. Global Journal Al-Thaqafah, 3(1), 67-84. https://doi.org/10.7187/gjat342013.03.01

Mohamed, H. A. B., Ab. Ghani, A. M., \& Basir, S. A. (2016). Factors influencing the implementation of Islamic QMS in a Malaysian public higher education institution. Total Quality Management and Business Excellence, 27(9-10), 1140-1157. https://doi.org/10.1080/14783363.2015.1064765

Mohd Noor, A. H., Abdul Rasool, M. S., Abdul Rahman, R., Md Yusof, R., \& Ali, S. M. (2012). Assessing performance of nonprofit organization: A framework for zakat institutions. British Journal of Economics, Finance and Management Sciences, 5(1), 12-22. https://doi.org/10.1613/jair.301

North, D. C. (1990). Institutions, Institutional Change, and Economic Performance. Cambridge University Press. https://doi.org/10.1017/CBO9780511808678

Nugroho, L., Doktoralina, C. M., Indriawati, F., Safira, S., \& Yahaya, S. (2020). Microeconomics and Tawhid String Relation Concept (TSR). International Journal of Economics and Business Administration (IJEBA), 8(3), 293-306. https://doi.org/10.35808/ijeba/516

Nugroho, L., Utami, W., \& Doktoralina, C. M. (2019). Ekosistem Bisnis Wisata Halal dalam Perspektif Maqasid Syariah (Halal Tourism Business Ecosystem in the Maqasid Syariah Perspective). Perisai : Islamic Banking and Finance Journal, 3(2), 84-92. https://doi.org/10.21070/perisai.v3i2.1964

Nugroho, L., Utami, W., Doktoralina, C. M., \& Husnadi, T. C. (2017). Islamic Banking Capital Challenges To Increase Business Expansion (Indonesia Cases). International Journal of Commerce and Finance, 3(2), 1-10.

Othman, K. (2016). Islamic Compliance Quality Management System (Icqms): An Analysis From Islamic Epistemology, Tasawwur And Ontology Perspectives. Universiti Sains Malaysia.

Prime Minister Office, M. (2019). Emulate Japanese for Success.

Rashid, M. A., Wahid, H., \& Ahmad, S. (2018). Analisis Faktor Penentu Kualiti Pengurusan Zakat: Kajian Terhadap Lembaga Zakat Selangor (LZS) di Sepang. Journal of Fatwa Management and Research, 11(1), 27-44. https://doi.org/10.33102/jfatwa.vol11no1.16

Salleh, M. S. (2003). Tujuh prinsip pembangunan berteraskan Islam. Zebra Editions Sdn. Bhd.

Sanusi, S. W. S. A., Tajuddin, T. S., Takril, N. F., \& Affandi, S. S. S. S. H. (2015). War 14 Successfulness of 
5s-Practices and Quality Productivity and Innovative Team Achievement of TQTFM in Zakat Institutions. World Academic and Research Congress 2015, December, 136-148.

Sanusi, Z. M., Johari, R. J., Said, J., \& Iskandar, T. (2015). The Effects of Internal Control System, Financial Management and Accountability of NPOs: The Perspective of Mosques in Malaysia. Procedia Economics and Finance, 28(April), 156-162. https://doi.org/10.1016/s2212-5671(15)01095-3

Siddaway, A., Wood, A. M., \& Hedges, L. V. (2019). How to Do a Systematic Review : A Best Practice Guide for Conducting and Reporting Narrative Reviews, Meta-Analyses, and Meta-Syntheses (Issue January). https://doi.org/10.1146/annurev-psych-010418-102803

Sundaram, J. K. (2014). 'Malaysia Incorporated': Corporatism a la Mahathir.' Institutions and Economies, 6(1), 73-94.

Wan Ali, W. Z. K., Ismail, A. Z., \& Mohaddaseh, A. (n.d.). The Status of Islam of Federal Constitution of Malaysia in comparison to IRI: An Analysis from the viewpoint of Islamic Thought. 1-17.

\section{Copyrights}

Copyright for this article is retained by the author(s), with first publication rights granted to the journal.

This is an open-access article distributed under the terms and conditions of the Creative Commons Attribution license (http://creativecommons.org/licenses/by/4.0/). 